\title{
Determination of charge carrier mobility in doped low density polyethylene using DC
} transients

\author{
Khalil, M.Salah; Henk, Peter O; Henriksen, Mogens
}

Published in:

Proceedings of the 3rd International Conference on Conduction and Breakdown in Solid Dielectrics

Link to article, DOI:

10.1109/ICSD.1989.69187

Publication date:

1989

Document Version

Publisher's PDF, also known as Version of record

Link back to DTU Orbit

Citation (APA):

Khalil, M. S., Henk, P. O., \& Henriksen, M. (1989). Determination of charge carrier mobility in doped low density polyethylene using DC transients. In Proceedings of the 3rd International Conference on Conduction and Breakdown in Solid Dielectrics (pp. 192-196). IEEE. https://doi.org/10.1109/ICSD.1989.69187

\section{General rights}

Copyright and moral rights for the publications made accessible in the public portal are retained by the authors and/or other copyright owners and it is a condition of accessing publications that users recognise and abide by the legal requirements associated with these rights.

- Users may download and print one copy of any publication from the public portal for the purpose of private study or research.

- You may not further distribute the material or use it for any profit-making activity or commercial gain

- You may freely distribute the URL identifying the publication in the public portal 
DETERMINATION OF CHARGE CARRIER MOBILITY IN DOPED LOW DENSITY POLYETHYLENE USING D.C. TRANSIENTS.

M. Salah Khal11, P.O. Henk, M. Henriksen

\section{ABSTRACT}

Charge carrier mobility has been determined for plain and doped low density polyethylene (LDPE) using d.c. transient currents. Barium titanate has been used as a strongly polar dopant and titanium dioxide as a semiconductive dopant. The values of the mobility obtained were within the range of $10^{-10} \mathrm{~cm}^{2} \mathrm{v}^{-1} \mathrm{~s}^{-1}$. Results indicate that the inclusion of 18 by weight of the BaTio and $\mathrm{THO}_{2}$ has a considerable effect on the conduction properties of the polymer. BaTio, has increased the charge carrier mobility by a factor of 3 and also increased the conductivity of the polymer. $\mathrm{TiO}_{2}$ has increased the charge carrier mobility by a factor of 5 . Charge trapping and space charge formation are modified by the introduction of titanium dioxide.

\section{INTRODUCTION}

Space charge formation in polymer insulation under $h . v . d . c$. conditions is one of the main problems in the development of h.v.d.c. cables with polymerlc insulation. The use of additives represents one of the methods to modify the space charge formation in polymeric materials [1]. Additives can also be used to provide an insight into the nature and origin of charge carriers as well as the electrical conduction mechanisms in polymers. It is well known that the nature of space charge is closely related to charge carriers and trapping effects. Recently, additives have been used to modify charge trapping and conductivity properties of linear low density polyethylene LLDPE [ 2 ].

Charge carrier mobility represents one of the essential parameters characterizing electrical conduction in polymers and is also closely related to charge carrler trapping in these materials. The experimental determination of the carrier mobilities in polymers is always beset with difficulties and the recorded results vary within large ranges. Mobility can be deduced from different techniques such as the time of flight measurements and surface charge dissipation method. Carrier mobilities in some polymers have also been evaluated from step voltage transient current measurements $[3,4,5]$. In the present work, the effect of both barium titanate as a strongly polar additive and titanium dioxide as a semiconductive additive on the charge carrier mobility in LDPE is investigated, using measurements of d.c. transients.

M. Salah Khalil, P.O. Henk and M. Henriksen are with the Technical University of Denmark, Dept. of Electric Power Engineering. 


\section{EXPERIMENTAL DETAILS}

The polymer used was a commerclal LDPE used for cable insulation with the following characteristics: density $0.925 \mathrm{~g} / \mathrm{cm}^{3}$, melt index $0.25 \mathrm{~g} / 10 \mathrm{~min}$. The specimens were discs, [1,8-2 $\mathrm{mm}]$ thickness and $175 \mathrm{~mm}$ diameter. LDPE was mixed with 18 by weight of either $\mathrm{BaTiO}_{3}$ or $\mathrm{TiO}_{2}$ by means of a double screw extruder prior to pressing. Gold electrodes were applied to the specimens by evaporation under vacuum after washing with pure alcohol. The specimens were thermally conditioned, under vacuum, in an evacuated chamber $\left(2-3 \times 10^{-3}\right.$ torr) at $40^{\circ} \mathrm{C}$ for 24 hours. Electrical conditioning was performed by applying $60 \mathrm{kV}$ for 24 hours, after mounting the specimens in the test set-up. The specimens were then shortcircuited for 24 hours at $40^{\circ} \mathrm{C}$ before starting the current measurements. D.C. transient currents were measured by applying 50 $\mathrm{kV}$ d.c. to the specimen for 6 days under $40^{\circ} \mathrm{C}$. Details of the measuring technique are described elsewhere [6].

\section{RESULTS AND DISCUSSION}

Fig. 1 shows the current time dependence in plain LDPE. In this case the current passes through a well defined peak with a value of maximum current $I_{m}=102 \mathrm{nA}$ after a time period $t_{m}$ of $6300 \mathrm{~s}$ after which 1 tecays towards to 1 ts steady state value $I_{\text {st }}$ of 14 nA. The current time dependence for $1 \%$ by weight BaTio 3 doped LDPE is shown in fig. 2. In this case $I_{m}=189 \mathrm{nA}$ and $t_{m}=1982 \mathrm{~s}$. The steady state current, Ist is $40 \mathrm{nA}$. Fig. 3 shows the current time dependence in $1 \%$ by welght $T 10^{2}$ doped LDPE. In this case, the current reaches its maximum value, $I_{m}=48 \mathrm{nA}$ after a time perlod, $t_{m}$ of $1262 \mathrm{sec}$, then decays fast to its steady state value which is $35 \mathrm{nA}$. It is evident in this case that the steady state current is reached much more faster when compared with the previous two cases; more over, the steady state current is about $70 \%$ that of the maximum current while it is $14 \%$ and $21 \%$ in the case of plain LDPE and $\mathrm{BaTiO}_{3}$ doped LDPE respectively.

The observed current maxima show similarities to the current transients observed before by a number of authors [3,4,5]. They are explained by the build-up of space charge of injected carriers [7]. A rough estimate of the effective mobility " eff of charge carriers can be obtained from the time of the current maximum $t_{\mathrm{m}}$ using the equation:

$\mu_{\text {eff }}=0.786 \mathrm{a} \mathrm{a}^{2} / \mathrm{U} \mathrm{t}_{\mathrm{m}} \ldots \ldots \mathrm{cm}^{2} \mathrm{v}^{-1} \mathrm{~s}^{-1}$

where "U" is the applied voltage in volts, "a" the sample thickness in $\mathrm{cm}$ and $t_{\mathrm{m}}$ is the time of maximum current in seconds.

TABLE 1 - Time of maximum current and effective mobility.

\begin{tabular}{|c|c|c|}
\hline Material & $\begin{array}{c}\text { Time of maximum current } \\
t_{\mathrm{m}}[\mathrm{sec} .]\end{array}$ & $\begin{array}{l}\text { Effective mobility } \\
\mu_{\text {eff }}\left[\mathrm{cm}^{2} \mathrm{v}^{-1} \mathrm{~s}^{-1}\right]\end{array}$ \\
\hline $\begin{array}{l}\text { PIain LDPE } \\
\text { LDPE + } \mathrm{BaTIO}_{3} \\
\text { LDPE + } \mathrm{THO}_{2}\end{array}$ & $\begin{array}{l}6300 \\
1982 \\
1262\end{array}$ & $\begin{array}{llll}0.9 & \times 10^{-10} \\
2.6 & \times & 10^{-10} \\
4.43 & \times & 10^{-10}\end{array}$ \\
\hline
\end{tabular}


Table 1 shows the effective mobility of charge carriers in the present specimens using equation 1 . Barlum titanate seems to increase the value of mobility and steady state current by an almost equal factor of about 3 times in comparison with plain LDPE.

Titanium dioxide has increased the mobility by a factor of 5 and the steady state current by a factor of 2.5 . The pattern of the current time characteristics in T1O doped LDPE (fig. 3), indicates possible modification of charge trapping and space charge formation due to the much less pronounced current peak and the fast arrival of the current to its steady state at a value very close to the peak value of the current, if compared with the case in plain and BaTiO, doped LDPE. The values of mobilities obtained in the present work compare favorably with the results obtained by other workers using different techniques as shown in table 2 .

TABLE 2 - Mobility of charge carriers in PE previously determined using different methods.

\begin{tabular}{|c|c|c|}
\hline Mobility & Experimental Method & Reference \\
\hline $\begin{array}{l}7 \times 10^{-11}-2 \times 10^{-11} \\
\left(\mathrm{~T}=71^{\circ} \mathrm{C}\right)\end{array}$ & $\begin{array}{l}\text { Maxima of d.c. transients } \\
\text { in oxidized LDPE }\end{array}$ & $\begin{array}{l}\text { Fischer and } \\
\text { Röhl [ } 3 \text { ] }\end{array}$ \\
\hline $\begin{array}{l}10^{-11}-10^{-8} \\
\left(\mathrm{~T}=40^{\circ} \mathrm{C}-80^{\circ} \mathrm{C}\right)\end{array}$ & $\begin{array}{l}\text { Maxima of d.c. transients } \\
\text { in plain and oxidized LDPE } \\
\text { and HDPE. }\end{array}$ & Ieda et aI [4] \\
\hline $\begin{array}{l}10^{-1} 1-10^{-9} \\
\left(\mathrm{~T}=60^{\circ} \mathrm{C}-120^{\circ} \mathrm{C}\right)\end{array}$ & $\begin{array}{l}\text { Maxima of d.c. transients } \\
\text { in graphite loaded LDPE }\end{array}$ & $\begin{array}{l}\text { H.st. Onge } \\
{[5]}\end{array}$ \\
\hline $\begin{array}{l}10^{-10}-10^{-8} \\
\left(\mathrm{~T}=70^{\circ} \mathrm{C}\right)\end{array}$ & Surface charge decay & Davies [8] \\
\hline $\begin{array}{l}10^{-4} \\
\left(T=20^{\circ} \mathrm{C}\right)\end{array}$ & $\begin{array}{l}\text { Photo current } \\
\text { investigation }\end{array}$ & $\begin{array}{l}\text { Tanaka and } \\
\text { Calderwood } \\
{[9]}\end{array}$ \\
\hline
\end{tabular}

All experimental data on carrier mobility in polymers show that its value is very low, which is evidently due to trapping [10]. Trapping sites exert a strong influence on the concentration of free carriers and their mobility. Although much speculation has been made on the nature of these trapping sites, it is generally conceded that charge trapping is primarily due to the basic polymer structure. Traps due to polymeric structure can be of various types, including chemical and morphological heterogeneities and structural defects. Recent luminescence studies [ 11] have shown that metallic impurities such as titanium can modify the trapping effect by combining with the defect states and annihilating the trap center. The present results seem to coincide with this picture. TiO, is considered as an n-type excess metal semiconductor with $\mathrm{T}^{2}+3$ ions and electrons occupying interstitial positions. The addition of $\mathrm{TiO}_{2}$ will give rise to donor levels which will act as a reducing agent to annihitate some of the defect sites, thus annealing the defect states of the 


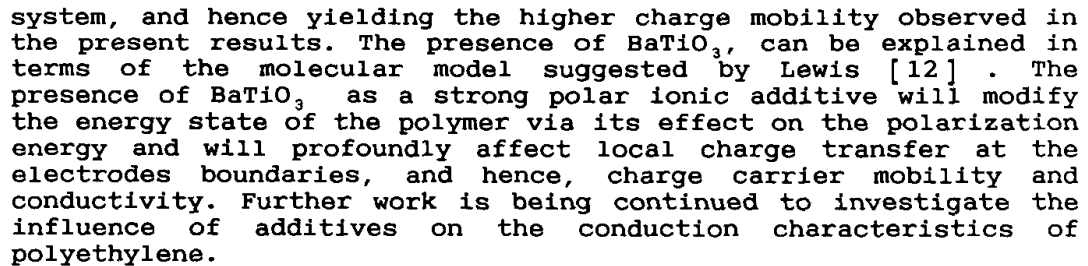
polyethylene.

\section{ACKNOWLEDGEMENTS.}

The authors are grateful to the Danish Technical Research Council for their financial support and to NKT Power Cables for supplying the materials.

\section{REFERENCES}

1. Khalil, M.S., Zaky, A.A. and Hansen, B.S., 1985 Ann.Rep., Conf. on Electr. Insul. \& Dielectr. Phenom, 143-149.

2. Perlman, M.M., and Haridoss, S., 1987, IEEE Trans on Electr. Insul., EI-22, 9-12.

3. Fischer, P. and Röhl,P., 1977, Prog. Colloid \& Polym.Sci, 62, 149-153.

4. Ieda, M., Mizutani, T., Tsukahara, T., and Suzuoki, Y., 1979 Ann.Rep., Conf. on Electr. Insul. \& Dielectr. Phenom, 106-113.

5. St. Onge, H., 1975 Ann. Rep., Conf. On Electr.Insul. \& Dielectr. Phenom, $6 \overline{32-639}$.

6. Henriksen, M., Larsen, E., and Johannesson, H., 1987, Ann. Rep., Conf. on Electr. Insul. \& Dielectr. Phenom, 106-113.

7. Many, A. and Rakavy, G., 1962, Phys. Rev, 126, 1980-1988

8. Davies, D.K., 1972, J.Phys. D: Appl. Phys., 5, 162-188.

9. Tanaka, T., and Calderwood, J.H., 1974, J.Phys. D: Appl.Phys., 7. $1295-1302$.

10. Kryszewski, M., 1975, J. Polymer Sci., Symposium, 50, 359-404.

11. Cheng, Y.C., Loutfy, R.O., 1980, J. Chem.Phys. 73 2911-2918

12. Lewis, T.J., 1984, IEEE Trans. on Electr.Insul., EI-19, 210-216. 


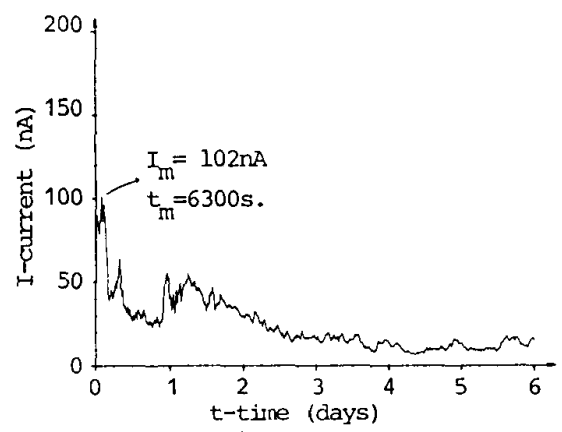

Figure 1. Current-time dependence in plain LDPE D.C, voltage $=50 \mathrm{kV}, \mathrm{T}=40^{\circ} \mathrm{C}$.

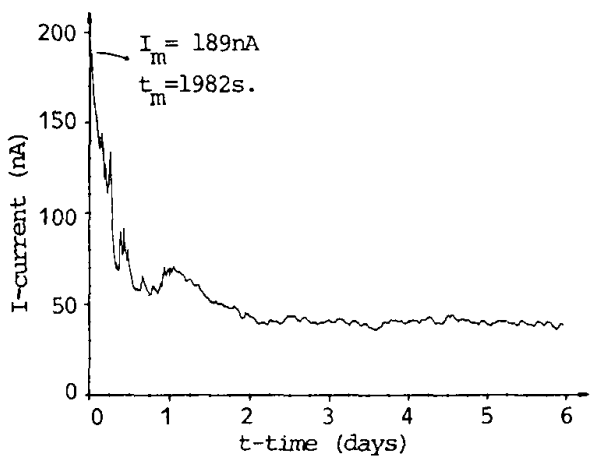

Figure 2. Current-time dependence in BaTio doped LDPE. D.C. voltage $=50 \mathrm{kV}, \mathrm{T}={ }^{3} 40^{\circ} \mathrm{C}$.

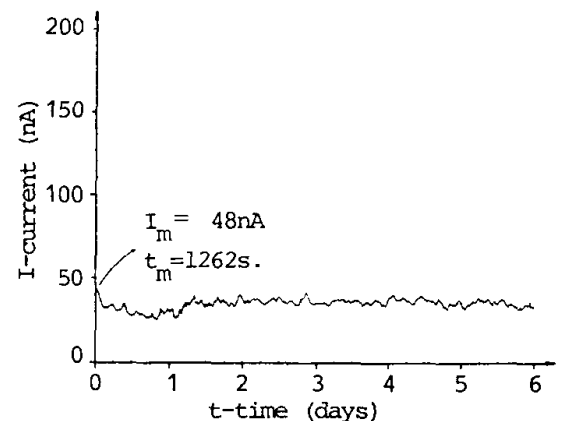

Figure 3. Current-time dependence in $\mathrm{TiO}_{2}$ doped LDPE. D.C. voltage $=50 \mathrm{kV}, \mathrm{T} \stackrel{2}{2} 40^{\circ} \mathrm{C}$. 